\title{
The wellness revolution is ayurveda the answer?
}

\author{
Volume 6 Issue 5 - 2017 \\ Linda Bretherton \\ Wise Earth Ayurveda Nutrition - Food, Breath and Sound, USA \\ Correspondence: Linda Bretherton, 64I Knutsford, Latchford \\ Village, Warrington Cheshire WA4 IJQ, USA, Tel 0044(0)1925 \\ 652435, Email lbretherton@btconnect.co
}

\section{Conceptual paper}

Ayurveda is the oldest form of healing the world has known and dates back over 5000years. It is becoming more recognised in the USA but is still relatively unknown in the UK. Ayurveda is a Sanskrit term meaning, "Ayu" or life, and "Veda" - knowledge, and is regarded as "The Science of Life" the practice involves the care of physical, mental and spiritual health of human beings.

Ayurveda is also based on sound ecological awareness taking into consideration the effects of seasonal and daily cycles of our lives. Ayurveda also considers the place of animals, birds and plants in relation to human life. The time honoured, well tested ancient formulas of Ayurvedic medicines use natural herbs, minerals and even gems, to cure disease and to promote immunity. The basis of Ayurveda and its influence on your health can be simplified to three fundamental principles of nature called Vata, Pitta, and Kapha these are also names for our body types or dosha. These three factors govern all our activities of mind, body and spirit and we are all a combination of all three, one usually being more predominate than the others. For example we could be predominantly Pitta, followed by Vata and then Kapha. When they are in balance, health is optimal. The main purpose of Ayurvedic is to establish balance in these three fundamental principles.

Ayurveda in the Wise Earth Tradition is a unique school of thought and practice developed by Maya Tiwari (previously Swamini Mayatitananda /Mother Maya) in her monastery school once nestled in the mountains of North Carolina. Mother Maya belongs to India's most ancient Vedic lineage that goes back to Veda Vyasa. This tradition has been maintained as an unbroken chain of the spoken word from generation to generation to this day.

Mother Maya has spend 25years restoring and introducing the ancient origins of Ayurveda - Sadhana -the long lost, grass roots knowledge and practice of nature's nourishers which are food, breath and sound (annavidya, pranavidya, and mantravidya). The Wise Earth Tradition teaches that nature's most potent medicine is inner medicine; it teaches us that we have the power to heal ourselves. Wise Earth's teachings focus on the cultivation of inner awareness and healing through every day life that is in accord with nature's rhythms.

Linda Bretherton has been trained by Mother Maya who has bestowed her with the honour of bringing this work to the UK. Linda is one of only a handful; of Wise Earth Master Trainers in the world and the only Master Trainer in the UK. She has a centre of learning where she teaches and practices the Wise Earth Philosophy. Linda also trains people to be Wise Earth Food Breath \& Sound Practitioners. 'We use ancient proven methods that our students can practice for themselves every day of their lives to reclaim their wholeness and radiance through the principles of 'Sadhana'. This is the way in which we integrate our lives with nature's rhythms and cultivate a nurturing, nourishing and compassionate relationship with ourselves and all of life. The ancient Vedas tell us that we all have the capacity for
Received: January II, 2016 | Published: April 26, 2017

wellness and that health cannot be found outside ourselves, it is our natural state of being.'

Sadhana practice creates wellbeing that encourages the body to heal itself through daily practice that involves every bite of food that we eat, every word that we utter, every breath that we take, every thought that we think, every choice that we make done in harmony with peaceful practices.

\section{Cardinal principles of wise earth sadhana}

i. Wholeness: Realizing the true self to be one with nature.

ii. Simplicity: Practicing humility through surrender to nature's intelligence.

iii. Harmony: Committing to harmony within and without.

iv. Memory: Restoring cosmic, cognitive, and ancestral memories.

v. Rhythm: Honouring nature's nourishers: Food, Breath and Sound.

vi. Sacred Practice: Aligning every activity in accord with nature's rhythms.

vii. Consciousness: Cultivating inner awareness and knowingness.

Anyone can learn the practices of daily Wise Earth Sadhana and we are all aware of the way health and wellbeing has deteriorated in our society - when we ignore our connections to nature's rhythms the cyclical, daily, seasonal, lunar, and solar aspects of our world we ignore the potential for self-healing and profound peace. Wise Earth Sadhana shows us that food, breath and sound are the three main nourishers of nature through which we can live ,be well and discover the true self, these are some of the most significant tools for selfhealing.

How do we do this in our everyday lives? We should always mindful of each moment. Sadhana can be practiced by simple breathing techniques, by thinking a compassionate thought, by saying a kind word, by noticing and reaching for a blade of grass, from eating healthy organic foods, taking the time to venture outdoors and sit in the sun and feeling its warmth or the wind on your face, touching the earth with bare feet. In short, Sadhana is the integral connection that 
keeps us forever dancing in rhythmic measure with the cosmic pulse. Our moment-to-moment awareness of this connection is the heart of Sadhana.

Understanding our body types (dosha) enables us to choose the correct practices to suit our individual problems and dis-ease. We can learn to choose the correct foods to balance our bodies system. We can do the exercises most appropriate, use the most effective oils, and what music will most likely bring about healing for ourselves. Knowing our personal body type enables us to know the best times of day or season that we can promote wellbeing or have a detox or any treatment.

\section{The 3 basic body types are vata, pitta, and kapha}

A. A balanced predominantly Vata person would have -
a. Stable mental alertness.
b. Proper formation of body tissues
c. Normal energy levels
d. Strong immunity
e. Sound sleep
f. Sense of exhilaration

B. A balanced predominantly Pitta person would have -
a. Normal heat and thirst mechanism
b. Strong digestion
c. Sharp intellect
d. Warm complexion
e. Contentment

C. A balanced predominantly Kapha person would have -
a. Muscular strength
b. Strong immunity
c. Affection, generosity, courage, dignity
d. Healthy ,Normal, Joints
e. Vitality and stamina
f. Stability of mind

D. When the Body Types are out of balance we would experience -Imbalanced Vata
a. Dry or Rough Skin
b. Constipation
c. Common fatigue ( non-specific cause )
d. Tension headaches
e. Underweight
f. Insomnia
g. Intolerance of cold
h. Anxiety, worry
E. Imbalanced Pitta
a. Rashes, skin inflammations
b. Heartburn
c. Premature greying, baldness

d. Hostility, irritability

e. Visual problems

f. Excessive body heat

F. Imbalanced Kapha
a. Oily skin
b. Sinus congestion
c. Obesity
d. Slow digestion
e. Nasal allergies
f. Lethargy, dullness

One of the foundations for balancing the body types is through the Six Tastes, the core of Ayurveda Nutrition. We are encouraged to include all six tastes in our daily meals and they are sweet, sour, salty, pungent, bitter and astringent tastes. These can be found in a variety of foods. When a body type is out of balance we can easily bring ourselves back into balance by eating the correct tastes relevant to our dosha.

One of the many delights of Ayurveda is the food that is prepared and cooked which is delicious and very nourishing. Many people believe that it is difficult to introduce the six tastes it to all meals not understanding that many of the tastes can be found in wonderful herbs and spices easily obtained from a local supermarket.

Examples of the six tastes and the types of food that we find them in are -Sweet: Sugar, milk, butter, rice, breads, Pasta.

a. Sour: Yogurt, lemon, cheese

b. Salty: Salt, sauces.

c. Pungent: Spices, ginger, hot peppers.

d. Bitter: Green leafy vegetables, Turmeric

e. Astringent: Beans, Lentils.

Depending on whether our body type requires decreasing or increasing will depend on which tastes that we need to add or subtract from our diet - until the imbalances is corrected. The following is a simple guideline to using the six tastes.

To Decrease a Vata imbalance eat foods that are - Sweet, Sour, Salty ToIncreasea Vataimbalanceeatfoods thatare-Pungent,Bitter,Astringent ToDecreaseaPittaimbalance eatfoods thatare-Sweet,Bitter,Astringent To Increase a Pitta imbalance eat foods that are - Pungent, Sour, Salty To Decrease a Kapha imbalance eat foods that are - Pungent, Bitter, Astringent To Increase a Kapha imbalance eat foods that are - Sweet, Sour, Salty It is said that all the six tastes should be included in your daily meals in a balanced way, so that you can benefit from the healing power of taste.

\section{Acknowledgments}

None.

\section{Conflicts of interest}

Author declares there are no conflicts of interest.

\section{Funding}

None. 